\title{
Use of Self 101: The Case for Teaching Personal Development in the Entrepreneurship Curriculum
}

$E$ ntrepreneurship education is rapidly growing, both in the number of schools offering programs and in the range of courses. But, survey data shows that entrepreneurship education is more likely to focus on bow to evaluate business opportunities, write a business plan, present a proposal to investors, and conduct analytical exercises to determine value. The success of a venture begins with the entrepreneur, and as students become entrepreneurs, they will need to wear a variety of "bats" and serve as the primary finance, marketing, buman resources, and operations person. High self-efficacy, emotional intelligence, and well-developed interpersonal skills have been shown to equate to a firm's success. These skills are rarely polished and perfected in the classroom. But, because they are so critical, more concentration on their development is needed in the entrepreneurship curriculum. This article presents the case and provides a model for developing "Use of Self" skills in the entrepreneurship classroom.

As an entrepreneur and an educator of future entrepreneurs, I believe that there are few opportunities more demanding of one's self than starting and running a new business. An entrepreneur may well be an expert in finance, marketing, and operations, and have a stellar business plan, but ultimately he or she must be able to manage "self" with a set of superior social skills. The entrepreneur must do all of these things: lead, inspire, persuade, create networks, excite, resolve conflict, initiate and manage change, and manage diverse groups of people, from the very first workday to the very last. We need to ensure that our students are the best they can be by creating experiential leadership skills courses and putting them in the entrepreneurship curriculum.

My conviction about the need for courses focusing on social skills and entrepreneurial leadership skills development is based on my own many years of experience in small business startups and management, a review of the small body of literature that agrees on the relationship of the presence of certain personal attributes and successful or effective entrepreneurship, and the surge in entrepreneurship, which demands entrepreneurial leaders with highly effective interpersonal skills. These demands are more pressing and per- haps more challenging than ever before, and require a "new breed" of entrepreneur who understands and is able to address the following trends in business:

- the global perspective now present in all business activities;

- the movement to knowledge-based enterprises from industrial-based enterprises;

- the evolving new company-employee relationship;

- the shift from management to leadership; and

- the focus on the entrepreneurial organization.

The relationship of social skills, such as social perception, impression management, persuasion and influence, and social adaptability to entrepreneurial success is supported by findings discussed in detail by Robert Baron and Gideon Markman (2000). They cite studies that link social capital and the use of related skills to better communication, closer alliances, more positive business relationships, and greater success with new ventures (Baron and Markman 2000).

Fernald et al. (2005) found that many of the characteristics attributed to leaders are also associated with successful entrepreneurs with these as the most common characteristics: being visionary, risk-taking, achievement-oriented, able to motivate, creative, flexible, persistent, and patient. And, Kuratko and Hodgetts (2007) developed a definition of entrepreneurship that includes these necessary attributes: the willingness to take calculated risks, the ability to formulate an effective venture team; the creative skills to marshal necessary resources; the skill to build a solid business plan; and the vision to recognize opportunity when others just see chaos; contradiction and confusion (Kuratko 2007; Kuratko and Hodgetts 2007). Much of entrepreneurial behavior is essentially leadership behavior (Fernald, Solomon, and Tarabishy 2005). The concept of entrepreneurial leadership may be considered a new paradigm of thinking about our understanding of entrepreneurship (Fernald, Solomon, and Tarabishy 2005).

There are many models and explanations of social skills and their value: what they are, how they are developed, how they are used, and the effect they may have on human relationships. I use the more complex and holistic model, Use of 
Self, developed by Dr. Charles Seashore (2004), which details a richer view of the behaviors that are related to social skills (Figure 1).

Use of Self is a complex concept that explains how we as individuals manage the intersection of the unconscious self and the conscious self, develop and implement our personal toolkit, and continually develop and grow as individuals to states of higher development. Skills necessary for honing this process are those that link personal potential and the world of change (Seashore et al. 2004). Use of Self addresses the "intentional, conscious and deliberate choices which result in actions/behaviors taken to bring about change (or the new venture startup)" (Seashore et al. 2004, p. 44). As Seashore et al. explained, the attributes of intentional (or conscious) Use of Self include

- agency - the ability to act as one's own agent in accomplishing courses of action;

- giving and receiving feedback-a process of continual- ly redirecting efforts based on the changing environment of people, process, and perceptions (Seashore, Seashore, and Weinberg 1997);

- reframing-the ability to perceive new perspectives and ways of organizing information;

- self-efficay-the belief in one's ability to successfully achieve the desired end (Bandura 1997);

- interpersonal skills-listening, goal-setting, conflict management, team building, stress management, building and sustaining effective relationships (Mattare 2006); and

- support systems - the ability to form a pool of resources from which one may draw on selectively (Seashore et al. 2004).

The offering of a personal development or entrepreneurial leadership skills development course in the undergraduate curriculum is infrequent compared to other course offerings. Reviews of the syllabi of those business courses that

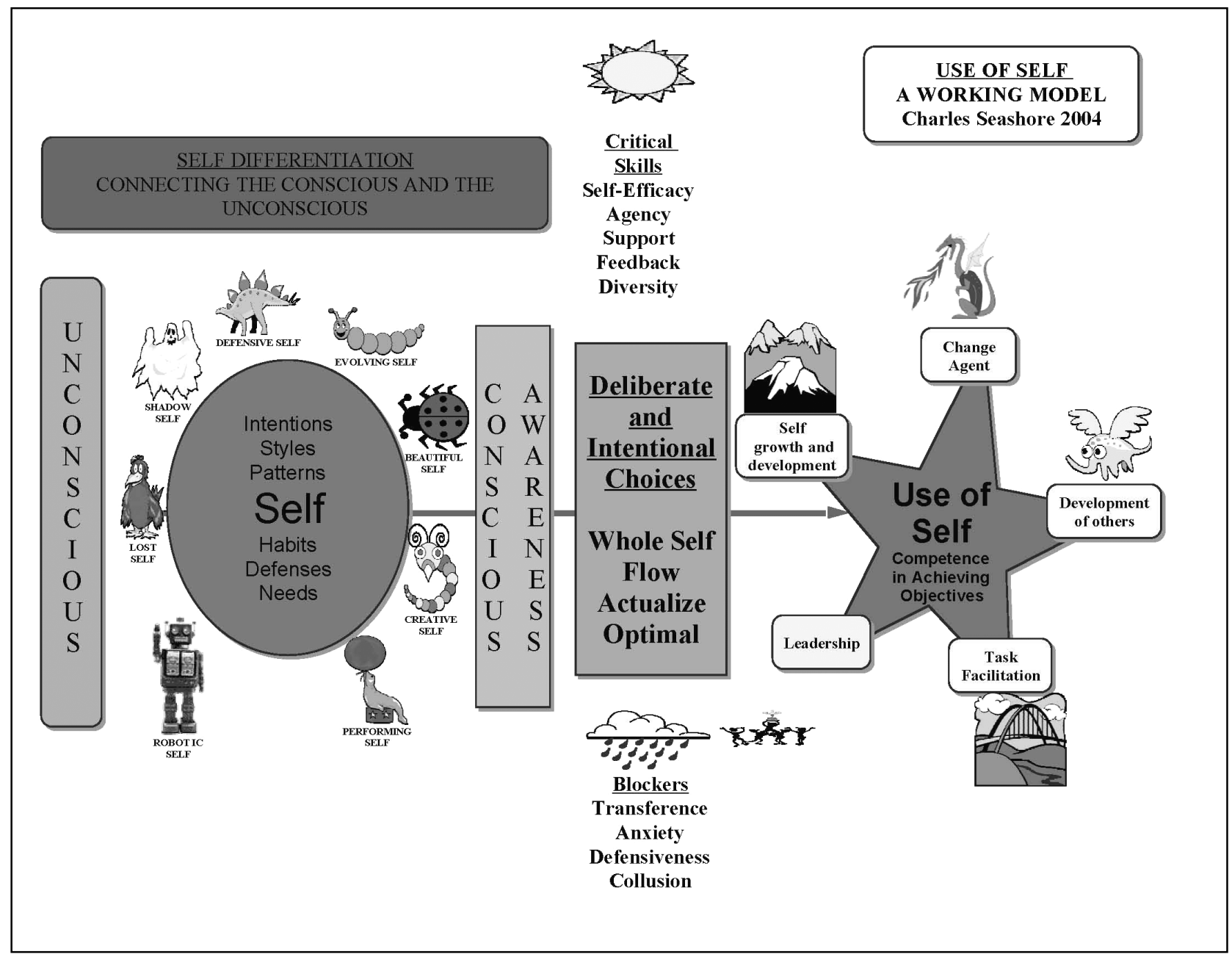

Figure 1. Seashore Model of Use of Self

Source: Seashore 2004. 
focus on entrepreneurial interpersonal skills and leadership development indicate that, there, the primary focus is on case studies. Few of the courses seem to be focused on actually developing students' individual skills. There are several programs that offer a major, minor, or certificate in entrepreneurial leadership. However, most entrepreneurship programs provide no more than the general course in Leadership that most business programs offer.

I define entrepreneurial leadership as

the ability to tap into self, understand one's strengths and weaknesses through superior intrapersonal and reflection skills, and manifest the best of those strengths through superior interpersonal skills that create positive effects and outcomes while practicing continual selfassessment and improvement.

Entrepreneurship education, as a relatively new business school discipline, most often falls into the category of management education. As of 2005, 1,600 schools offered courses related to entrepreneurship (Kuratko 2005). I conducted a review of the entrepreneurship curricula of Entrepreneur magazine and The Princeton Review's 4th and 6th annual top 25 undergraduate programs. I classified a course as specifically oriented to entrepreneurship if the course title contained terms such as "entrepreneurial/ship" or "new business ventures," and it was listed in the entrepreneurship curriculum. The top 25 list is compiled annually and evaluates undergraduate and graduate programs in entrepreneurship based on a survey that provides data about programs, students' entrepreneurship, community partnerships and other criteria that are then evaluated by top entrepreneurship educators (Entrepreneur Magazine and The Princeton Review's 6th annual top 25 entrepreneurial colleges, 2008).The review of the curricula shows that entrepreneurship courses fall into categories similar to the generic categories of subject areas in business courses, for example: finance, marketing, strategy, technology, and business plan creation but with titles specifically identifying them as entrepreneurship courses. When the courses were categorized, based on course name and/or available syllabi, it is evident that entrepreneurship programs emphasize the development of intellectual or cognitive skills with a focus on the creation of business plans. This focus is undeniably important; every entrepreneur should create a solid working business plan at some point, although many new ventures are created without a business plan (Gartner, Carter, and Reynolds 2004). It is unusual, however, to find courses devoted to the development of interpersonal skills which, ultimately, are the skills that will most likely propel the entrepreneur to success.Although it is the case that most business programs offer general courses in organizational behavior, leadership, and other human development and behavior-oriented courses, there are few that focus specifically either on these areas as they relate to the practice of entrepreneurship or focus on the actual development and practice of interpersonal skills, such as those mentioned.

The development and practice of interpersonal skills is a labor of love for the instructor. It is time consuming and requires a carefully planned set of steps that use classroom techniques that are experiential in design and include: fish bowl exercises, videotaping with feedback session, role play, practice in real-life settings, evaluation, then revise, repeatuntil the skills become comfortable to the student. It takes time on the part of the instructor since there must be first a foundation of trust in the classroom. And, before serious work can begin, certain basic skills must be developed such as the art of giving and receiving feedback, a critical component of this process, as well as the skills involved with the interpretation of nonverbal language-facial expressions, "body" language, and tone of voice, which is a "major medium of conversation in our everyday life" (Henley 1977). And, it takes great patience to accommodate students while they work their way through the process and students who don't recognize the value of the exercises or are deeply afraid of trying them.

Educating the future entrepreneur calls for an emphasis on practice. David Kirby discusses the need for a paradigm shift in business schools, from educating "about" entrepreneurship to educating "for it" (Kirby 2004). Kirby goes on to advocate a focus on creativity and change rather than just new venture creation and small business management (Kirby 2004). My own research with home-based entrepreneurs who created successful enterprises largely due to their extraordinary "use of selves" (Mattare 2006), as well as my experience as an entrepreneur, supports this viewpoint. Management of change, creative thinking, and superior interpersonal skills are the differentiators between entrepreneurial success and failure. With entrepreneurship on the rise and entrepreneurial behavior encouraged to both initiate new business startups and to foster development in the established organization, there are clearly expanded requirements for entrepreneurship education, both in number of offerings as well as scope.We are in the process of sending ever greater numbers of newly graduated entrepreneurship majors or minors into the world to start or run new businesses. Although technically competent, we may ask if these students are as fully self-developed as they could be. Are they informed enough to capitalize on their strengths and supplement their weaknesses? Have we adequately prepared them for the personal challenges of the turbulent, rollercoaster ride of entrepreneurship?

\section{Literature Review}

Research shows that entrepreneurial success is linked to the 
personal characteristics of entrepreneurs more than any other factor (Allinson, Chell, and Hayes 2000; Baron and Markman 2000; Baum and Locke 2004; Begley and Boyd 1987; Bird 1989; Blanchflower and Oswald 1998; Chattopadhyay 2002; Crane 2007; Gatewood et al. 2003; McClelland 1961). Considerable literature may be found addressing various aspects of entrepreneurial personality and behavior characteristics, such as in Swayne and Tucker's 1973 book, The Effective Entrepreneur. The authors argued that successful entrepreneurs have unique personalities, behaviors, and characteristics that differentiate them from managers or nonentrepreneurs (Swayne and Tucker 1973). Other earlier authors, in attempts to quantify entrepreneurs and entrepreneurship, developed various classifications or typologies that named attributes or characteristics of entrepreneurs. Smith (1967) defined two types of entrepreneurs: the opportunistic type who drives a more adaptive and growth-oriented firm, and the craftsman type who is less educated, is socially adept, and drives a less dynamic firm (Smith 1967). There is controversy regarding any relationship between personality characteristics and entrepreneurship. This criticism is centered on the lack of consistent definitions of entrepreneurship and the use of psychometric tools that have unknown or unacceptable reliability or validity (Llewellyn and Wilson 2003; Miner 2000; Morris 2002).

Further pursuit of the linkage of personality traits to entrepreneurship by, for example, Bird (2003), Begley and Boyd (1987) and Singh, DeNoble, and Kakousova (2002) focused on entrepreneurial vision, intentionality, and Big 5 personality traits (Begley and Boyd 1987; Bird 1988, 1989, 1992, 2003; Singh, De Noble, and Kakousova 2002). Mixed results from these lines of pursuit turned researchers to cognitive psychology and variables such as overconfidence, planning fallacy, general self-efficacy, regretful thinking, and entrepreneurial decision-making (Bhide 1994; Busenitz 1999; Mitchell et al. 2002).

A moderate number of research studies have used the MBTI to look at entrepreneurial characteristics. The MBTI helps to understand entrepreneurs in that this instrument, different from other personality instruments, identifies an individual's status on one or the other of "opposite personality categories" which represent multifaceted psychological domains (Myers et al. 1998). Individuals are "sorted" into opposite categories of domains represented in the MBTI rather than measured in the degree of a trait. In addition, the MBTI dichotomies "are concerned with basic attitudes and mental functions that enter into almost every aspect of behavior" (Myers et al. 1998).

In 1993, Hoy and Carland, used the MBTI to differentiate entrepreneurs from managers. They found that "entrepreneurs were more intuitive, thinking, and perceptive than managers" (Caird 1993). Reyneirse used the MBTI a number of times and found that Ns dominated; NTPs were the most likely entrepreneurial type; Ps were associated with entrepreneurism; Js were bureaucratic types; and there were more EP, $\mathrm{NP}$, and TP types than Js among entrepreneurs. His research found no differences on the S-N preference scales (Reynierse 1997 a, b; Reynierse et al. 2000). I found in a recent research study that Ns predominated (80\%) (Mattare 2006).

I have used the MBTI in the classroom to help students understand how they energize themselves (extraversion $\mathrm{v}$. introversion), how they perceive information (sensing v. intuiting), how they judge what they perceive (thinking v. feeling), and how they deal with the outside world (judging $\mathrm{v}$. perceiving). The use of the MBTI offers instructors and students opportunities to learn more about self, others, and to practice Use of Self in the classroom.

Entrepreneurship is a very broad area in which many dramatically different personality types operate. This challenges any attempt to arrive at universal definitions or methods of quantifying the field. Cooper, Markman, and Niss (2000) defined three potential paths of future research on entrepreneurship: a traditional path, or "normal" science operating with empirically tested hypotheses; a multiple-paradigm path that combines methods and theories from many disciplines, such as economics, sociology, and psychology; and a pragmatic, less theory-driven path that looks to address immediate and relevant questions flowing from the classroom full of potential entrepreneurs (Cooper, Markman, and Niss 2000).

A few areas of entrepreneurship research are often agreed upon.

- The entrepreneur recognizes opportunity in different ways than others (Kickul and Gundry 2002).

- The entrepreneur tends to be an MBTI iNtuitor (Caird 1993; Carland 1982; Mattare 2006).

- The entrepreneur typically has higher-than-average selfefficacy (Chen, Greene, and Crick 1998; DeNoble, Jung, and Ehrlich 1999; Mattare 2006).

- Training programs positively impact self-efficacy (De Noble, Jung, \& Ehrlich, 1999; Ehrlich et al. 2005).

- The entrepreneur has a high need for achievement (McClelland 1961).

- Social skills can enhance entrepreneurial success (Baron and Markman 2000).

These areas of agreement are ones where educators may draw practical applications for the classroom, linking research and practice in meaningful ways.

\section{Interpersonal Skills Development in the Entrepreneurship Classroom}

I surveyed Entrepreneur magazine's 2008 top 25 undergraduate programs by reviewing courses-and syllabi-listed as 
specifically dedicated to entrepreneurship programs and found that the most frequent subject areas offered were finance, internships, and introductory entrepreneurship, followed by strategy, marketing, legal/global issues, and opportunity development (Figure 2).

A comparison from a prior survey of courses and syllabi from the 2006 top 25 undergraduate programs shows some interesting shifts in course focus from then to the current top 25 programs (Table 1 ).

One of the most interesting aspects about the changes from 2006 to 2008 is the surge of internship programs. However, courses that specifically address entrepreneurial leadership and/or entrepreneurial personal development have only increased from 4 percent of programs to 16 percent of programs. The increase is encouraging, but not yet enough, in my view.

\section{Discussion}

Few endeavors call more for individuals to "make things happen" than the entrepreneurial enterprise. The entrepreneur may have to wait a period of time for the results of his or her efforts, all the while maintaining vision and adjusting and fine-tuning strategy positions. He or she must build an inter- nal and external support infrastructure that is flexible and adaptable. And, he or she must maintain a strong belief in his or her ability to successfully achieve the desired end. These are skills that can be learned through the use of experiential exercises, practice, and feedback, which are measurable by various, proved instruments.

I suggest there are 10 critical interpersonal skills that effective entrepreneurs possess. Each of these skills can be taught, enhanced, and improved in the classroom.

1. Understanding others: Being able to accurately "read" and understand others: reading nonverbal messages; understanding others' intentions, needs, wants.

2. Sending messages: Giving others the impression you want them to have (looking and acting professional; responding appropriately; making others feel good about themselves).

3. Listening: Using active listening techniques that allow you to get the information you need and ask artful questions.

4. Providing feedback: Being able to give and receive and reflect upon solid, constructive feedback for greater learning.

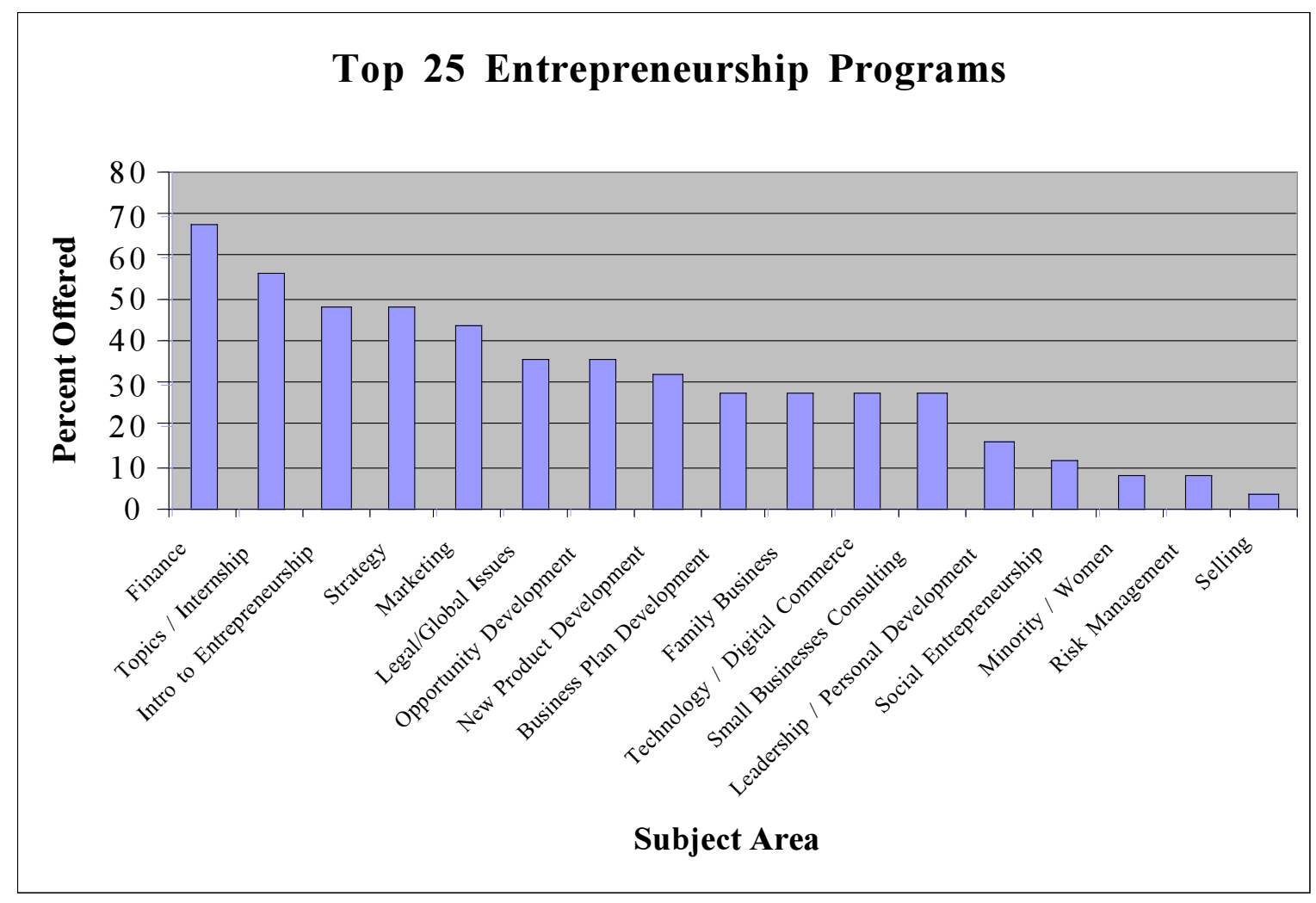

Figure 2. Course Types at 2008 List of Top 25 Undergraduate Schools of Entrepreneurship Source: Entrepreneur.com 2008. 
5. Empowering people: Allowing others to develop under your guidance.

6. Promoting change: Convincing others to follow your guidance and vision.

7. Persuading: Being able to change others' attitudes, beliefs, and behavior.

8. Resolving conflicts: Having the ability to constructively address and resolve conflict, deflect anger, and provide satisfaction with resolution.

9. Negotiating: Being able to negotiate the outcome you desire and making it a "win-win" situation.

10. Generating excitement: Being able to create a sense of excitement and enthusiasm in others.

The above skills are assessable either by observation in experiential environments or by accepted instruments, such as those named in the list below. Behaviors or characteristics and the attendant scale or approaches to assessing skills are

- Self-efficacy: General Self-Efficacy Scale (Schwarzer and Jerusalem 2000)
- Personality assessment: MBTI ${ }^{\circledR}$ (Myers and Myers 1998)

- Attitude toward achievement:Tall Poppy Scale (adapted) (Feather 1989)

- Locus of control: Locus of Control Scale (Rotter 1966 in Neil 2006)

- Tolerance of ambiguity (Nutt 1988)

- Emotional intelligence: EQ-I (BarOn 1997)

- Need for inclusion and affection: FIRO-B (Schutz 1960)

- Giving and receiving feedback: Feedback Model used/observed in action

- Cognitive orientation:Wechsler Adult Intelligence test or Stanford Binet IQ Test

- Perseverance (Stoltz 1997)

The above areas of assessment and development may be addressed using a model such as the one in Figure 2, an adaption of the TQM model of Plan, Do, Check, Act. Embedded in the model is Kolb's 4-state cycle of experiential learning which, throughout the cycle, moves from concrete experience, to reflective observation, to abstract conceptualization, to active experimentation (Kolb 2004, Sternberg 2001). The

Table 1. Course Types by Percentage Compared from 2006 to 2008

\begin{tabular}{|c|c|c|c|}
\hline Subject Area Offered & $\begin{array}{l}2006 \\
\% \text { of Schools } \\
\text { Offering Subject }\end{array}$ & $\begin{array}{l}2008 \\
\% \text { of Schools } \\
\text { Offering Subject }\end{array}$ & $\begin{array}{l}\text { Increase/Decrease } \\
\text { from } 2006 \text { to } 2008\end{array}$ \\
\hline Finance & $44 \%$ & $68 \%$ & $24 \%$ \\
\hline Internship & $0 \%$ & $56 \%$ & $56 \%$ \\
\hline Introduction to Entrepreneurship & $44 \%$ & $48 \%$ & $4 \%$ \\
\hline Strategy & $12 \%$ & $48 \%$ & $36 \%$ \\
\hline Marketing & $28 \%$ & $44 \%$ & $16 \%$ \\
\hline Legal/Global Issues & $8 \%$ & $36 \%$ & $28 \%$ \\
\hline Opportunity Development & $4 \%$ & $36 \%$ & $32 \%$ \\
\hline New Product Development & $4 \%$ & $32 \%$ & $28 \%$ \\
\hline Business Plan Development & $16 \%$ & $28 \%$ & $12 \%$ \\
\hline Family Business & $8 \%$ & $28 \%$ & $20 \%$ \\
\hline $\begin{array}{l}\text { Technology/Digital Commerce/ } \\
\text { E-Commerce }\end{array}$ & $8 \%$ & $28 \%$ & $20 \%$ \\
\hline Consulting & $8 \%$ & $28 \%$ & $20 \%$ \\
\hline Leadership/Personal Development & $4 \%$ & $16 \%$ & $12 \%$ \\
\hline Social Entrepreneurship & $0 \%$ & $12 \%$ & $12 \%$ \\
\hline $\begin{array}{l}\text { Minority/Women-owned } \\
\text { Businesses }\end{array}$ & $4 \%$ & $8 \%$ & $4 \%$ \\
\hline Risk Management & $0 \%$ & $8 \%$ & $8 \%$ \\
\hline Selling & $16 \%$ & $4 \%$ & $-12 \%$ \\
\hline Family Business & $8 \%$ & $0 \%$ & $-8 \%$ \\
\hline
\end{tabular}


Skills Development 5-Cycle Model demonstrates the process of improving on critical skills and has been used with good results in the classroom.

The processes as defined in the model are interactive and interrelated and involve the following action steps:

- Assess for skill levels: This involves utilizing the complete set of assessments or observed activities.

- Design the plan and resulting activities: In this step, the student or client works with the instructor or coach to design a personal plan and practice the activities (extensive practice in small groups and videotaping of activities occurs at this step).

- Receive feedback: Givers and receivers of feedback not only learn a well-thought feedback model but also use the feedback to refine the activities.

- Repeat and perfect: Incorporation of feedback and repractice.

- Repeat assessment: Post-assessment to determine skill development.

This model is useful in that it first provides a process to use in the development and practice of interpersonal skills. The model is one that may be used by individual students as a map of their learning journey as it interacts with their use of self during the process. This requires self-reflection at each step of the process. A classroom application of how this model works in the development and practice of the interpersonal skills of active listening and giving and receiving feedback is as follows: ${ }^{1}$

1.Assess: In this phase, models for active listening and feedback are presented to students. The students preread assignments on active listening and feedback skills and take several self-assessments found in the texts (Garner 1980; Johnson 1999; Seashore, Seashore, and Weinberg 1997).

2. Design: Students share and discuss the self-assessment scores in small groups. Working in these small teams, students design scenarios based on real experiences where, upon reflection, they could have been more effective.

3. Practice: In the same small groups students form roleplay groups of two or three and practice their new scenarios. Students take turns practicing active listening and giving and receiving feedback. These sessions are videotaped.

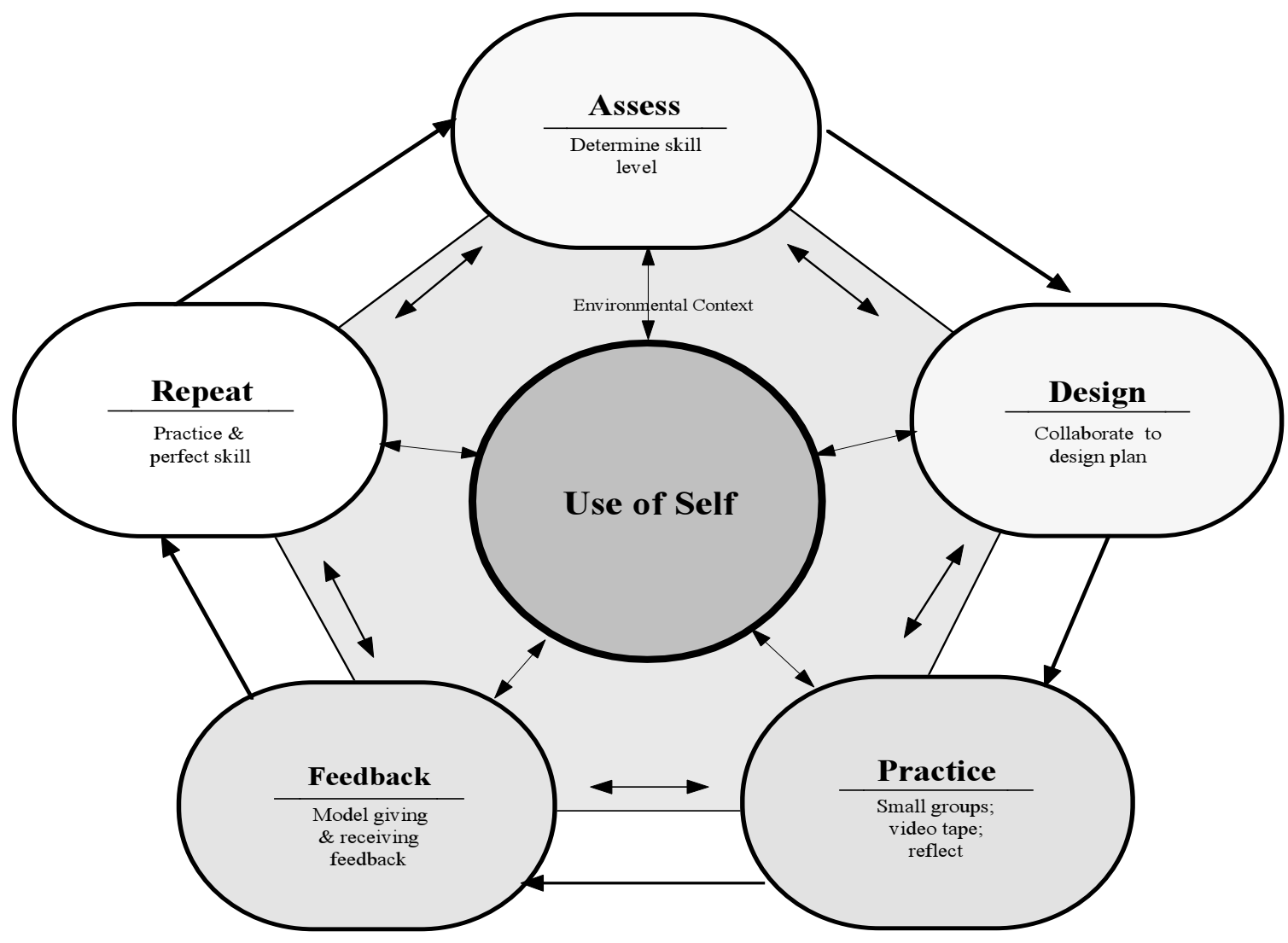

Source: Mattare 2007.

Figure 3. Skills Development 5-Cycle Model 
4. Feedback: Each student then provides feedback to the members of his or her small group about the exercise and the perceived effectiveness of the role play. Receiving feedback as per the provided model is also practiced.Videotapes are observed.

5. Repeat: The sessions are repeated until the students feel comfortable with the use of the active listening skills model and the feedback model and they feel they have arrived at an effective way to address their real life situation.

6. Use of Self: Throughout these steps, the constant process of self-reflection is practiced through journaling, small and large group discussions, and individual feedback from the instructor. Self-reflection is integrated into the constant practice and perfection of superior interpersonal skills. This part of the model is central, ongoing, interactive, and iterative, in that as students progress through the classroom exercises they gain confidence in their abilities to handle a wide range of challenging situations.

The entrepreneurship educator is in the best position to better prepare entrepreneurs to use self to accomplish their new venture objectives. The case for incorporating the teaching of these skills into the entrepreneurship curriculum in my view is strong and can be facilitated either by integration of experiential teaching techniques or by the creation of a dedicated course (Kuratko 2005; Mattare 2008; Solomon, Duffy, and Tarabishy 2002). For those who consult or coach small business owners, there will be important opportunities to contribute to successful outcomes by helping entrepreneurs develop these skills.

\section{Conclusion}

Entrepreneurship slices across all areas of the business curriculum. Without question, successful entrepreneurs should be operationally informed of finance, marketing, strategy, and human resource management. The groundwork for understanding each of these areas is laid in the general courses offered in the business curriculum that teach entrepreneurial finance, marketing, human resource management, and leadership, and enhanced in those courses that dwell specifically on entrepreneurship.

But, entrepreneurs will also be leaders facing extraordinary demands, and so a more practical approach must be taken in the entrepreneurship classroom than is taken in other business school classrooms. Among entrepreneurship educators, there has been a struggle to determine what is needed in the entrepreneurship classroom that goes beyond traditional business courses (Solomon, Duffy, Tarabishy 2002). In my view, it is critical that the entrepreneurship student learn to do, to act, to self-reflect, and to learn from fail- ure or mistakes by quickly regrouping, attempting and reattempting an action. The entrepreneurship student needs to have a good understanding of self, tools for selfimprovement, strong self-efficacy, and the ability to deal constructively with failure and try again. These requirements demand not only a different approach in course design but a much greater focus on the individual's potential for full Use of Self.

Entrepreneurship in the United States is on the rise. More than half of all businesses are small business enterprises and the annual rate of startups is growing. The combined number of entrepreneurship students for the 2006 top 25 undergraduate programs alone was close to 10,000 . Not all of these students will become entrepreneurs for sure, but the ones who do will need to be prepared in ways that go beyond expertise in finance, marketing, and preparing business plans. What will count is the "who" behind the business plan and how well that person will navigate the social world.

Some entrepreneurship course texts do discuss the "who" of entrepreneurship, for example: Timmons and Spinelli's New Venture Creation and Buskirk, Davis, and Price's Fast Trac ${ }^{\circledR}$ field guide (Buskirk, Davis, and Price 2004; Timmons and Spinelli 2007). Many texts discuss the traits and characteristics of entrepreneurs (Allen 2007; Barringer and Ireland 2006; Hitt et al. 2002; Katz and Green 2007; Mariotti 2007; Zimmerer and Scarborough 2005). However, none that I've reviewed spends time developing the self-knowledge, selfreflection, and interpersonal skills that will be critical in practice.

Over the years, I have found the resources listed in Table 2 quite helpful in creating and executing skills development exercises in the classroom.

\section{Recommendations}

The entrepreneurship classroom that focuses on development of leadership skills-those superior interpersonal skills previously discussed-presents an opportunity to address both the "lighter" and the "darker" sides of entrepreneurship by teaching core skills and anticipating extraordinary stresses. The student will learn the desired behaviors in settings using, for example, fish bowl exercises, role plays, simulations, and games. The actual practice of skills in the safe setting of the classroom will arm the student with an arsenal to take into the business world.A course devoted to these areas, placed at the beginning of the entrepreneurship curriculum, will prepare students for the unique challenges they will face not only as students but ultimately as entrepreneurs. This premise builds on prior research, such as that conducted by Kirby (2004), Baron and Markman (2000), and Fernald et al. (2005), or the perspectives put forth by Kuratko (2007), or the entrepreneurial leadership course outcomes discussed by Okudan and Rzasa (2004) (Baron and Markman 2000; 
Fernald, Solomon, and Tarabishy 2005; Kirby 2004; Kuratko 2007; Okudan and Rzasa 2004). The outcomes from instituting the development of personal skills in the entrepreneurship curriculum will allow students to have knowledge of self, coupled with real tools to develop self, so that they are able to consciously employ Use of Self to build their new ventures. In a practical sense, if students understand who they are and how they absorb, process, and act upon information, they will be able to do a better job to build the infrastructure of support that fills in the gaps.

It will be important to determine the effect of adding such a course to the entrepreneurship curriculum and there would be number of potential research opportunities that could measure the relationship of small venture performance to entrepreneurial leadership courses. These would measure

- changes in self-efficacy scores, either during the entrepreneurial leadership course or over the span of courses in the curriculum;

- situational self-efficacy and the entrepreneurial venture (Mattare 2006);

- the role of self-reflection and entrepreneurial success;

- the relationships of various assessments, such as locus of control, emotional intelligence, need for inclusion and affection and others to entrepreneurial success; and

- social networks and entrepreneurial success.

\section{Summary}

Business schools are rapidly starting entrepreneurship programs or expanding their course offerings (Mattare 2008). The demand of globalization creates even more pressure for the development of unique skills. There is very little more demanding than starting and running a business. Every day, all day, the entrepreneur faces extraordinary pressures that require tapping into the highest levels of social and interpersonal skills. The development of those skills begins with the process of self-reflection and knowledge of self. The proposed outline of skill development and the process provided using the model described in this article will form a formal approach to be used either by the instructor in the classroom or by the executive or business coach.

\begin{tabular}{|c|}
\hline Table 2. Resources for Instructors \\
\hline Books \\
\hline $\begin{array}{l}\text { 1. Fritz, S. M., J. P. Lunde, W. Brown, and E. Banset. } 2004 \text {. } \\
\text { Interpersonal skills for leadership. Saddle River, NJ: Prentice- } \\
\text { Hall. }\end{array}$ \\
\hline $\begin{array}{l}\text { 2. Garner, A. 1980. Conversationally speaking:Tested new ways } \\
\text { to increase your personal and social effectiveness. Los } \\
\text { Angeles: Lowell House. }\end{array}$ \\
\hline $\begin{array}{l}\text { 3. Henley, N. M. 1977. Body politics. New York: A Touchstone } \\
\text { Book, published by Simon \& Schuster. }\end{array}$ \\
\hline $\begin{array}{l}\text { 4. Hunkins, F. P. 1989. Teaching thinking through effective ques- } \\
\text { tioning. Boston: Christopher-Gordon Publishers. }\end{array}$ \\
\hline $\begin{array}{l}\text { 5. Johnson, D. W. 1999. Reaching out; interpersonal effectiveness } \\
\text { and self-actualization, } 7 \text { th ed. Boston:Allyn and Bacon. }\end{array}$ \\
\hline $\begin{array}{l}\text { 6. McDrury, J., and M.Alterio. 2002. Listening through story- } \\
\text { telling in higher education: Using reflection \& experience to } \\
\text { improve learning. London: Kogan Page. }\end{array}$ \\
\hline $\begin{array}{l}\text { 7. Robbins, S. P., and P. L. Hunsaker. 2008. Training in interper- } \\
\text { sonal skills, } 5 \text { th ed. Saddle River, NJ: Prentice-Hall }\end{array}$ \\
\hline $\begin{array}{l}\text { 8. Seashore, C., E. W. Seashore, and G. M. Weinberg. 1997. What } \\
\text { did you say? The art of giving and receiving feedback. } \\
\text { Columbia, MD: Bingham Books. }\end{array}$ \\
\hline $\begin{array}{l}\text { 9. Schultz, K. 2003. Listening: A framework for teaching across } \\
\text { differences. New York:Teachers College Press. }\end{array}$ \\
\hline Articles \\
\hline $\begin{array}{l}\text { 1. Hunsaker, J. S. } 1983 \text {. Taking the sting out of negative feed- } \\
\text { back: How to criticize constructively. Industrial Management } \\
\text { 25(6): 5-6. }\end{array}$ \\
\hline $\begin{array}{l}\text { 2. Michaelsen, L.K., and E. E. Schultheiss. 1988. Making feedback } \\
\text { helpful. Organizational Behavior Teaching Review 13(1): } \\
\text { 109-113. }\end{array}$ \\
\hline $\begin{array}{l}\text { 3. Seashore, C., M. Mattare, M. N. Shawver, and G.Thompson. } \\
2004 \text {. Doing good by knowing who you are:The instrumental } \\
\text { self as an agent of change. OD Practitioner } 36(3), 42-46 .\end{array}$ \\
\hline Workshop \\
\hline $\begin{array}{l}\text { 1.American Management Association. 2008. Interpersonal skills } \\
\text { for managers } \# 2575 \text {. New York:AMA. }\end{array}$ \\
\hline
\end{tabular}

\section{Note}

1. Classroom exercises are based on materials adapted from those developed by Professor Marion Leonard (Leonard 2003).

\section{References}

Allen, K. 2007. Growing and managing a small business: An entrepreneurial perspective, 2nd ed. Boston: Houghton Mifflin Company.

Allinson, C. W., E. Chell, and J. Hayes. 2000. Intuition and entrepreneurial behaviour. European Journal of Work and Organizational Psychology 9(1), 31-43. 
Bandura,A. 1997. Self-efficacy: the exercise of control. New York:W. H. Freeman and Company.

Barringer, B. R., and R. D. Ireland. 2006. Entrepreneurship: Successfully launching new ventures. Upper Saddle River, NJ: Pearson/Prentice Hall.

Baron, R.A., and G. D. Markman. 2000. Beyond social capital: How social skills can enhance entrepreneurs' success. The Academy of Management Executive 14(1), 106.

BarOn, R. 1997. EQ-i. www.EQ-i.org. Retrieved October 15, 2008.

Baum, J. R., and E.A. Locke. 2004. The relationship of entrepreneurial traits, skill, and motivation to subsequent venture growth. Journal of Applied Psychology 89(4), 587-598.

Begley,T. M., and D. P. Boyd. 1987. Psychological characteristics associated with performance in entrepreneurial firms and smaller businesses. Journal of Business Venturing 2(1), 79.

Bhide, A.V. 1994. How entrepreneurs craft strategies that work. Harvard Business Review March-April, 150.

Bird, B. J. 1998. Implementing entrepreneurial ideas: the case for intention. Academy of Management:The Academy of Management Review 13(3), 442.

Bird, B. J. 1989. Entrepreneurial behavior. Glenview, IL: Scott, Foresman \& Company.

Bird, B. J. 1992. The operation of intentions in time: the emergence of the new venture. Entrepreneurship:Theory and Practice 17(1), 11.

Bird, B. J. 2003. What is entrepreneurial vision and how does it work? Unpublished Working paper.American University. 2003

Blanchflower, D. G., and A. J. Oswald. 1998. What makes an entrepreneur? Journal of Labor Economics 16(1), 26-60.

Busenitz, L. 1999. Entrepreneurial risk and strategic decision making. The Journal of Applied Behavioral Sciences 35(3), 325.

Buskirk, R. H., R. M. Davis, and C. Price. 2004. Fast trac:Venture planning field guide. Kansas City, MO: Kauffman Foundation.

Caird, S. P. 1993. What do psychological tests suggest about entrepreneurs? Journal of Managerial Psychology 8(6), 11.

Carland, J.W. 1982. Entrepreneurship in a small business setting:An exploratory study. Unpublished doctoral dissertation. University of Georgia.

Chattopadhyay, R. 2002. Predicting entrepreneurial success. Journal of Entrepreneurship 11(1), 21-31.

Chen, C. C., P. G. Greene, and A. Crick. 1998. Does entrepreneurial self-efficacy distinguish entrepreneurs from managers? Journal of Business Venturing 13(4), 295-317.

Cooper, A. C., G. D. Markman, and G. Niss. 2000. The evolution of the field of entrepreneurship. In G. D. Meyer and K.A. Heppard, eds., Entrepreneurship as Strategy: Competing on the Entrepreneurial Edge. Thousand Oaks, CA: SAGE Publications, Inc., p. 115.

Crane, F. G. 2007. Management principles: the theory of management: dispositional optimism and entrepreneurial success. The Psychologist-Manager Journal 10(1), 13-25.

DeNoble, A., D. Jung, and S. B. Ehrlich. 1999. Entrepreneurial self-efficacy:The development of a measure and its relationship to entrepreneurial action. Retrieved May 18, 2005, from http://www.babson.edu/entrep/fer/papers99/I/I_C/IC\%Text.htm.

Ehrlich, S. B., A. DeNoble, D. Jung, and D. Pearson. 2005. The impact of entrepreneurship training programs on an individual's entrepreneurial self-efficacy. Retrieved July 7, 2005, from http://www.babson.edu/entrep/fer/XXXVII/XXXVIIB/html/xxxvii-b.htm.

Entrepreneur.com. 2008. Entrepreneur \& The Princeton Review's 4th annual top 25 entrepreneurial colleges. Retrieved from http://www/entrepreneur.com/topcolleges/undergrad/index.html.

Entrepreneur Magazine and The Princeton Review's 6th annual top 25 entrepreneurial colleges 2008. Retrieved November 21, 2008, from http://www.entrepreneur.com/topcolleges.

Feather, N.T. 1989. Attitudes towards the high achiever: the fall of the tall poppy. Australian Journal of Psychology 41(3), 239-267.

Fernald, L. W., G.T. Solomon, and A.Tarabishy. 2005. A new paradigm: Entrepreneurial Leadership. Southern Business Review 30(2), 1-13.

Garner, A. 1980. Conversationally speaking:Tested new ways to increase your personal and social effectiveness. Los Angeles: Lowell House. 
Gartner, W. B., N. M. Carter, and P. D. Reynolds. 2004. Business start-up activities. Handbook of entrepreneurial dynamics. Thousand Oaks, CA: SAGE Publications.

Gatewood, E. J., K. G. Shaver, J. B. Powers, and W. B. Gartner. 2003. Entrepreneurial expectancy, task effort, and performance. Entrepreneurship:Theory and Practice, 95.

Henley, N. M. (1977). Body politics. New York, NY:A Touchstone Book, published by Simon \& Schuster.

Hitt, M.A., R. D. Ireland, S. M. Camp, and D. L. Sexton, eds. 2002. Strategic entrepreneurship: Creating a new mindset. Oxford, United Kingdom: Blackwell Publishers.

Johnson, D. W. 1999. Reaching out; interpersonal effectiveness and self-actualization, 7th ed. Boston:Allyn and Bacon.

Katz, J.A., and R. P. Green. 2007. Entrepreneurial small business. New York: McGraw-Hill/Irwin.

Kickul, J., and L. K. Gundry. 2002. Prospecting for strategic advantage:The proactive entrepreneurial personality and small firm innovation. Journal of Small Business Management 40(2), 85.

Kirby, D.A. 2004. Entrepreneurship education: can business schools meet the challenge? Education + Training 46(8/9), 510-519.

Kolb, D.A. 2004. David A. Kolb on experiential learning. Retrieved February 23, 2004, from http://www.infed.org/biblio/bexplrn.htm.

Kuratko, D. F. 2005. The emergence of entrepreneurship education: development, trends, and challenges. Entrepreneurship: Theory and Practice 29(5), 2005, 577-594.

Kuratko, D. F. 2007. Entrepreneurial leadership in the 21st century.Journal of Leadership and Organizational Studies 13(4).

Kuratko, D. F., and R. M. Hodgetts. 2007. Entrepreneurship: Theory, Process, Practice (7th ed.). Mason, OH:Thomson/South Western Publishing.

Leonard, M. 2003. Classroom materials for MGMT 509. Unpublished classroom materials. Frostburg State University.

Llewellyn, D. J., and K. M. Wilson. 2003. The controversial role of personality traits in entrepreneurial psychology. Education $\varepsilon$ Training 45(6), 341.

Mariotti, S. 2007. Entrepreneurship: Starting and operating a small business. Upper Saddle River, NJ: Pearson/Prentice Hall.

Mattare, M. 2006. Entrepreneurial strategies:The relationship to MBTI and self-efficacy. Santa Barbara, CA,The Fielding Graduate University.

Mattare, M. 2007. Teaching entrepreneurship: The case for an entrepreneurial leadership course. Frederick, MD, Frostburg State University: 18.

Mattare, M. 2008. Teaching entrepreneurship: the case for an entrepreneurial leadership course. Paper presented at USASBE, January 10-12. San Antonio, TX.

Mattare, M. 2008. Facilitating use of self: a teaching \& coaching model for entrepreneurial success. Paper presented at the International Academy of Business Disciplines, April 5. Houston, TX.

McClelland, D. C. 1961. The achieving society. Toronto: Collier-Macmillan Canada Ltd.

Miner, J. B. 2000. Testing a psychological typology of entrepreneurship using business founders. The Journal of Applied Behavioral Sciences 36(1), 43.

Mitchell, R. K., L. Busenitz, T. Lant, P. P. McDougall, E.A. Morse, J. B. Smith. 2002. Toward a theory of entrepreneurial cognition: Rethinking the people side of entrepreneurship research. Entrepreneurship: Theory and Practice (Winter), 93.

Morris, M. H. 2000. Revisiting “who” is the entrepreneur." Journal of Developmental Entrepreneurship 7(1).

Myers, P. B., M. H. McCaulley, N. L. Quenk, and A. L. Hammer. 1998. MBTI manual:A guide to the development and use of the Myers-Briggs Type Indicator (3rd ed.). Palo Alto, CA: Consulting Psychologists Press, Inc.

Myers, P. B., and K. D. Myers. 1998. MBTI Self-scorable form M. Mountain View, CA: CPP, Inc.

Neil, J. 2006. Locus of control-A class tutorial. Retrieved October 19, 2007, from http://wilderdom.com/games/ descriptions/LocusOfControlExercise.html.

Nutt, P.C. 1988. The tolerance for ambiguity and decision making. The Ohio State University College of Business Working Paper Series, WP88-291. 
Okudan, G. E., and S. E. Rzasa. 2004. Teaching entrepreneurial leadership: a project-based approach. Paper presented at the 34 th ASEE/IEEE Frontiers in Education Conference.

Reynierse, J. H. 1997a. An MBTI model of entrepreneurism and bureaucracy:The psychological types of business entrepreneurs compared to business managers and executives. Journal of Psychological Type 40, 3-19.

Reynierse, J. H. 1997b. Who is an entrepreneur? Paper presented at the Myers-Briggs Indicator and Leadership Conference. Washington, DC.

Reynierse, J. H., D. Ackerman, A. Fink, and J. B. Harker. 2000. The effects of personality and management role on perceived values in business settings. International Journal of Value-Based Management 13(1), 1-13.

Schutz, W. C. 1960. FIRO: A three-dimensional theory of interpersonal behavior. New York: Holt, Rinehart and Winston, Inc.

Schwarzer, R., and M. Jerusalem. 2000. Generalized self-efficacy scale. In J. Weinman, S. Wright, and M. Johnston, eds., Measures in health psychology: a user's portfolio. Windson, UK: NFER-NELSON, pp. 35-37.

Seashore, C. 2004. Use of self model. Inspiration. Columbia, MD.

Seashore, C., M. Mattare, M. N. Shawver, and G.Thompson. 2004. Doing good by knowing who you are: The instrumental self as an agent of change. OD Practitioner 36(3), 42-46.

Seashore, C., E. W. Seashore, and G. M. Weinberg. 1997. What did you say? The art of giving and receiving feedback. Columbia, MD: Bingham Books.

Singh, G., A. F. De Noble, and L. Kakousova. 2002. The Big-Five personality factors and entrepreneurial intention. (Paper). Babson Park, MA: Babson College.

Smith, N. R. 1967. The entrepreneur and his firm: The relationship between type of man and type of company. East Lansing, MI: Michigan State University.

Solomon, G.T., S. Duffy, and A.Tarabishy. 2002. The state of entrepreneurship education in the United States: a nationwide survey and analysis. International Journal of Entrepreneurship Education 1(1), 65-86.

Sternberg, R. J. 2001. Perspectives on thinking, learning, and cognitive styles. Philadelphia: Lawrence Erlbaum.

Stoltz, P.G. 1997. Adversity quotient:Turning obstancles into opportunities. New York: John Wiley.

Swayne, C., and W. Tucker. 1973. The effective entrepreneur. Morristown, NJ: General Learning Press.

Timmons, J.A., and J. Stephen Spinelli. 2007. New venture creation: Entrepreneurship for the 21st century, 7th ed. New York: McGraw-Hill/Irwin.

Zimmerer,T.W., and N. M. Scarborough. 2005. Essential of entrepreneurship and small business management, 4th ed. Upper Saddle River, NJ: Pearson/Prentice Hall.

\section{About the Author}

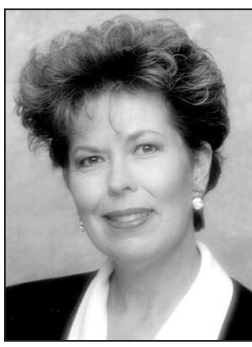

\section{MEjE}

MARTY MATTARE (mmattare@frostburg.edu), MBA, MA, PhD, is an assistant professor at Frostburg State University, Frostburg, Maryland. Dr. Mattare has authored two books, numerous articles, workshops, and conference papers. She worked for years in various businesses and founded several of her own. Marty is active in USASBE, SCORE, and other professional organizations. 